\begin{abstract}
Iranica
Abstracta Iranica Revue bibliographique pour le domaine irano-aryen

Volume 34-35-36 | 2017

Comptes rendus des publications de 2011-2013
\end{abstract}

\title{
Mark B. Garrison. Royal Achaemenid iconography
}

\section{Astrid Nunn}

\section{(2) OpenEdition}

\section{Journals}

Édition électronique

URL : http://journals.openedition.org/abstractairanica/41681

DOI : 10.4000/abstractairanica.41681

ISSN : 1961-960X

Éditeur :

CNRS (UMR 7528 Mondes iraniens et indiens), Éditions de l'IFRI

\section{Référence électronique}

Astrid Nunn, « Mark B. Garrison. Royal Achaemenid iconography », Abstracta Iranica [En ligne], Volume 34-35-36 | 2017, document 82, mis en ligne le 15 juillet 2016, consulté le 03 octobre 2020. URL : http:// journals.openedition.org/abstractairanica/41681 ; DOI : https://doi.org/10.4000/abstractairanica. 41681

Ce document a été généré automatiquement le 3 octobre 2020.

Tous droits réservés 


\title{
Mark B. Garrison. Royal Achaemenid iconography
}

\author{
Astrid Nunn
}

\section{RÉFÉRENCE}

Mark B. Garrison. « Royal Achaemenid iconography », in : D.T. Potts, éd., The Oxford Handbook of Ancient Iran. New York, Oxford University Press, 2013 p. 566-595.

1 À la présentation des archives suit celle de l'iconographie royale achéménide qui se base essentiellement sur les impressions de sceaux sur tablettes, mais aussi sur le relief de Behistun et les quelques reliefs de Pasargades. Le règne de Darius marque un tournant pendant lequel l'image royale sera codifiée: le roi, assis ou debout, est soit entouré de fonctionnaires, soit il est debout devant un autel, maîtrise des animaux réels ou imaginaires ou tire à l'arc. D'autres scènes, telles les compositions antithétiques de créatures réalistes ou mythiques, les lions et les taureaux n'incluent pas le roi mais se réfèrent à l'iconographie royale.

\section{AUTEURS}

\section{ASTRID NUNN}

Université de Munich 